\title{
RAGE Does Not Affect Amyloid Pathology in Transgenic ArcA $\beta$ Mice
}

\author{
Ivana Vodopivec ${ }^{a} \quad$ Arnaud Galichet $^{a, b}$ Marlen Knobloch ${ }^{a}$ Angelika Bierhaus $^{c}$ \\ Claus W. Heizmann ${ }^{b}$ Roger M. Nitsch ${ }^{a}$ \\ ${ }^{a}$ Division of Psychiatry Research and b Division of Clinical Chemistry and Biochemistry, Department of Pediatrics, \\ University of Zurich, Zurich, Switzerland; ' ${ }^{\circ}$ Department of Medicine I and Clinical Chemistry, University of \\ Heidelberg, INF 410, Heidelberg, Germany
}

\section{Key Words}

Alzheimer's disease $\cdot$ RAGE $\cdot$ Amyloid- $\beta$ peptide . Insulin-degrading enzyme $\cdot$ Angiotensin-converting enzyme $\cdot$ Neprilysin $\cdot$ Microglia $\cdot Y$ maze

\begin{abstract}
Background: Alzheimer's disease (AD) is characterized by brain accumulation of the amyloid- $\beta$ peptide $(A \beta)$ that triggers a cascade of biochemical and cellular alterations resulting in the clinical phenotype of the disease. While numerous experiments addressed $A \beta$ toxicity, the mechanisms are still not fully understood. The receptor for advanced glycation end products (RAGE) binds $A \beta$ and was suggested to be involved in the pathological processes of AD. Objective: Our purpose was to assess the effect of RAGE deletion on A $\beta$-related pathology. Methods: We crossed RAGE knockout $\left(\mathrm{RAGE}^{--}\right)$mice with transgenic mice harboring both the Swedish and Arctic $A \beta$ precursor protein mutations ( $\operatorname{arc} A \beta$ mice). We assessed $A \beta$ levels, $A \beta$ brain deposition, $A \beta$-degrading enzyme activities, $A \beta$ precursor protein expression and processing, number and morphology of microglia as well as cognitive performance of 6- and 12-month-old $\mathrm{RAGE}^{-/-} / \operatorname{arcA} \beta, \mathrm{RAGE}^{-/-}$, $\operatorname{arcA} \beta$ and wild-type mice. Results: $\mathrm{RAGE}^{-/-} / \operatorname{arc} \mathrm{A} \beta$ mice had significantly lower levels of SDSand formic-acid-extracted $A \beta$ in the cortex and hippocam-
\end{abstract}

\section{KARGER}

Fax +4161306 1234 E-Mail karger@karger.ch www.karger.com

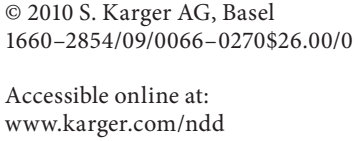

pus, with concomitantly increased activity of insulin-degrading enzyme at the age of 6 months. However, RAGE deletion could neither prevent the decline in cognitive performance nor the age-related cerebral accumulation of $A \beta$ peptide. Furthermore, histological analysis revealed no difference in the microglia-occupied brain areas or microglial morphologies between $\mathrm{RAGE}^{-/-} / \operatorname{arc} \mathrm{A} \beta$ and $\operatorname{arcA} \beta$ mice. Conclusions: Together, our results indicate that while the absence of RAGE was associated with increased insulin-degrading enzyme activity in the brain, it was not sufficient to prevent or ameliorate cognitive deterioration, $A \beta$ accumulation and microglial activation in the $\operatorname{arc} A \beta$ mouse model of $A D$.

Copyright $\odot 2010$ S. Karger AG, Basel

\section{Introduction}

Alzheimer's disease (AD), the most common form of dementia, is characterized by progressive cognitive deficits with underlying amyloid- $\beta$ peptide $(A \beta)$ accumulation, neuronal dysfunction and neuroinflammation. Both the evolution of neuronal impairment and inflammatory processes in $\mathrm{AD}$ pathology are suggested to be a result of receptor-mediated interactions with $A \beta$. One candidate receptor is the receptor for advanced glycation
Ivana Vodopivec

Division of Psychiatry Research, University of Zurich

August Forel-Strasse 1

$\mathrm{CH}-8008$ Zurich (Switzerland)

Tel. +41 4463488 86, Fax +41 4463488 74, E-Mail ivana.vodopivec@ bli.uzh.ch 
end products (RAGE), a multiligand receptor belonging to the immunoglobulin superfamily [1]. To determine the phenotype of brain $\beta$-amyloidosis in the absence of RAGE, we developed a mouse model, $\mathrm{RAGE}^{-/-} / \operatorname{arcA} \beta$. $\operatorname{Arc} A \beta$ mice, which overexpress the human $\beta$-amyloid precursor protein (APP) with both the Swedish and the Arctic mutations, show first cognitive deficits at the age of 6 months [2]. At that age, the animals have abundant $\mathrm{A} \beta$ intracellular punctate deposits in the cortex and hippocampus with no apparent $A \beta$ plaque load. At 12 months of age, $A \beta$ plaques and cerebral amyloid angiopathy (CAA) are prominent features. Therefore, we analyzed the $\mathrm{RAGE}^{-/-} / \operatorname{arcA} \beta$ mice at 6 and 12 months of age, and tested their cognitive abilities, biochemical and histopathological changes, including brain $A \beta$ levels, plaque load, CAA and microglial morphology. $\mathrm{RAGE}^{-/-} / \operatorname{arcA} \beta$ animals showed significantly lower levels of SDS- and formic-acid-extractable $A \beta$ in the cortex and hippocampus presumably related to concomitant increases in insulin-degrading enzyme (IDE) activity, as compared with $\operatorname{arcA} \beta$ mice at the age of 6 months. However, these differences did not result in better cognitive performance and were no longer detectable 6 months later when massive $\mathrm{A} \beta$ accumulation occurs.

\section{Materials and Methods}

\section{Animals}

RAGE knockout $\left(\mathrm{RAGE}^{-/-}\right)$mice [3] were crossed with $\operatorname{arcA} \beta$ mice [2] to generate the $\mathrm{RAGE}^{-/-} / \operatorname{arcA} \beta$ mouse model. The $\operatorname{arcA} \beta$ model is based on the overexpression of human APP 695 with the Swedish (K670N/M671L) and the Arctic (E693G) mutations in a single construct under the control of the prion protein promoter. There were 4 genotypes investigated in parallel: $\mathrm{RAGE}^{-/-}$ $\operatorname{arcA} \beta$ mice, their respective $\mathrm{RAGE}^{-/-}$littermates, $\operatorname{arcA} \beta$ and their respective wild-type littermates. Six- and 12-month-old mice, 8-9 animals per genotype and age, were analyzed. Each animal group was balanced for gender. The mice were kept under standard housing conditions and a reversed 12-hour light/dark cycle, with free access to food and water. The animal experiments were approved by the Cantonal Veterinary Authority of Zurich. The abrogation of RAGE expression in $\mathrm{RAGE}^{-/-}$animals was demonstrated by Western blot of lung tissue, both directly by detecting no RAGE signal and indirectly by demonstrating reporter EGFR expression (online supplementary fig. 1, www. karger.com/doi/10.1159/000261723).

\section{Y Maze}

The spontaneous alternation rate was assessed using a Yshaped plastic maze, with $40 \times 20 \times 10 \mathrm{~cm}$ arm sizes. During 5 -min sessions, the sequences of arm entries were recorded; alternation was defined as successive entries into 3 arms, in overlapping triplet sets. The percent alternation was calculated as the ratio of actual to possible alternations (defined as the total num- ber of arm entries -2$) \times 100 \%$. The behavioral testing was performed in the dark phase.

\section{Tissue Preparation}

Within 1 week of Y maze testing the mice were anesthetized with ketamine-xylazine cocktail $(10 \mathrm{mg} / \mathrm{kg}$, i.p.) and flush-perfused transcardially with ice-cold phosphate-buffered saline. Brains were rapidly removed and divided sagittally. One hemibrain was postfixed in phosphate-buffered $4 \%$ paraformaldehyde and paraffin-embedded; the other hemibrain was dissected into cortex, hippocampus and cerebellum snap-frozen and stored at $-80^{\circ} \mathrm{C}$ for protein analysis.

\section{Histology}

Five-micrometer-thick sagittal sections were cut with a Leica RM 2135 microtome. The sections were pretreated with citrate buffer $\left(20 \mathrm{~min}\right.$ in microwave at $\left.85{ }^{\circ} \mathrm{C}\right)$ followed by $95 \%$ formic acid (FA) [( 5 min at room temperature (RT)], and blocked with $4 \%$ bovine serum albumin, $5 \%$ goat serum and $5 \%$ horse serum at RT for $1 \mathrm{~h}$. The sections were subsequently incubated with primary antibodies overnight at $4{ }^{\circ} \mathrm{C}$ at the following dilutions: mouse 6 E10 (1:500); rabbit anti-Iba1 (1:500). Secondary fluorophoreconjugated antibodies were used for $2 \mathrm{~h}$ at RT. Thioflavin $\mathrm{S}$ staining was done according to standard protocol. Automated plaque and microglia counting was performed on 6 sections from each animal, spaced $50 \mu \mathrm{m}$ apart, using the software Image J (http:// rsb.info.nih.gov/ij/). The measurements were limited to the cortex, which was analyzed in the frontal and parietal regions, and the hippocampus.

\section{Three-Step A $\beta$ Extraction Protocol}

Cortices were homogenized in 10 tissue volumes (w/v) of $1 \%$ Triton X-100 buffer (50 mM of Tris-HCl, pH 8.0/1\% Triton X-100/ complete protease in hibitor cocktail, Roche) with Teflon glass homogenizer (40 strokes) and subsequently centrifuged at 100,000 $\mathrm{g}$ for $1 \mathrm{~h}$ at $4^{\circ} \mathrm{C}$. The supernatant was retained as the $1 \%$ Triton $\mathrm{X}$ 100 soluble fraction. The resulting pellet was homogenized in 10 tissue volumes (w/v) of $2 \%$ SDS buffer $(50 \mathrm{~mm}$ of Tris- $\mathrm{HCl}, \mathrm{pH}$ 8.0/2\% SDS/2 mM EDTA/complete protease inhibitor cocktail EDTA-free, Roche) and centrifuged at $100,000 \mathrm{~g}$ for $1 \mathrm{~h}$ at $8^{\circ} \mathrm{C}$. The ensuing supernatant was collected as the $2 \%$ SDS soluble fraction. Given the small amount of tissue obtained per hemibrain, mouse hippocampi were homogenized in 10 tissue volumes (w/v) of $1 \%$ Triton X-100, 2\% SDS buffer ( $50 \mathrm{~mm}$ of Tris- $\mathrm{HCl}, \mathrm{pH}$ 8.0/1\% Triton X-100/2\% SDS/complete protease inhibitor cocktail, Roche) with Teflon glass homogenizer (40 strokes) and subsequently centrifuged at $100,000 \mathrm{~g}$ for $1 \mathrm{~h}$ at $8^{\circ} \mathrm{C}$. Two percent SDS pellets from cortices and hippocampi were further extracted with a minimum of $225 \mu \mathrm{l}$ of $70 \% \mathrm{FA}$ and spun at $100,000 \mathrm{~g}$ for $1 \mathrm{~h}$ at $8^{\circ} \mathrm{C}$. The FA supernatant was collected by aspiration, avoiding the surface lipid layer and the acid insoluble bottom pellet. Aliquots of the $70 \%$ FA soluble fraction were lyophilized overnight in order to remove the acid and stored at $-80^{\circ} \mathrm{C}$.

\section{Immunoblots}

Tissue extracts were separated by SDS-PAGE using 10-20\% Tricine gels (Invitrogen) and transferred onto nitrocellulose membranes. After an optional epitope retrieval and blocking in 5\% milk TBS-T, the membranes were probed with 6 E10 (1:500, Signet), 22C11 (1:1,000, Chemicon International), anti-APP C-terminal 
(1:4,000, Sigma), anti-mouse/rat RAGE (1:500, R\&D Systems; 1:1,000 rabbit polyclonal antibodies against RAGE V, C1 and C2 domains [4]) and anti-GFP (1:1,000, Roche) antibodies. Immunopositive bands were visualized by chemiluminescence (ECL, Amersham Biosciences) and subsequently quantified by densitometric analysis of their intensity levels. $\beta$-Tubulin was used as loading control (1:10,000, Sigma). The results were expressed as signal intensities normalized to values pertaining to $\operatorname{arc} \mathrm{A} \beta$ animals.

\section{$A \beta 40$ and $A \beta 42$ ELISA of Cerebral $A \beta$}

The $A \beta 40$ and $A \beta 42$ quantities in the above-mentioned fractions were determined using hAmyloid $\beta 40$ and hAmyloid $\beta 42$ ELISA kits (The Genetics Company AG, Switzerland).

Enzymatic Assays

Cortical tissue from 4 mice per genotype was pooled. The pooled tissue was homogenized in a 4 -fold (w/v) volume of $20 \mathrm{~mm}$ Tris- $\mathrm{HCl}$ (pH 7.4), 0.5\% Triton X-100, $10 \mu \mathrm{M}$ PMSF. Homogenate was centrifuged at $13,000 \mathrm{rpm}$ for $15 \mathrm{~min}$ at $4^{\circ} \mathrm{C}$. Supernatant was used as a sample for the assay. The protein concentration was determined with the BCA Protein Assay (Pierce) and measured against bovine serum albumin standards.

IDE Activity Assay. The IDE activity in the supernatant was determined with the fluorometric Innozyme Insulysin/IDE Immunocapture Activity Assay Kit (Calbiochem, Merck) according to the manufacturer's instructions. The reaction time was $1 \mathrm{~h}$. The IDE activity was expressed in nanograms/milliliter of crude cortical homogenates that were normalized to $2 \mathrm{mg} / \mathrm{ml}$ protein concentration.

Angiotensin-Converting Enzyme Activity Assay. The angiotensin-converting enzyme (ACE) activity in the supernatant against the synthetic substrate N-hippuryl-L-histidyl-L-leucine was determined using an ACE colorimetric kit (Buhlmann Laboratories AG, Schönenbuch, Switzerland). The reaction time was $3 \mathrm{~h}$.

Neprilysin Activity Assay. The neprilysin enzyme activity was measured as described previously $[5,6]$, using a fluorometric assay for the generation of free dansyl-D-Ala-Gly (DAG) from $\mathrm{N}$ dansyl-Ala-Gly-D-nitro-Phe-Gly (DAGNPG; Sigma), a fluorogenic substrate for neprilysin. Substrate solutions containing $1 \mathrm{mM}$ of DAGPNG and $10 \mu \mathrm{M}$ of enalapril (Sigma) in $20 \mathrm{~mm}$ of Tris $\mathrm{HCl}$ with and without the addition of $10 \mu \mathrm{M}$ of NEP inhibitor phosphoramidon were prepared and preincubated at $37^{\circ} \mathrm{C}$ for 10 min. Enalapril, an ACE inhibitor, was added to prevent ACE-mediated DAGNPG cleavage. Fifty micorliters of the sample were incubated for $1 \mathrm{~h}$ with $100 \mu \mathrm{l}$ of each substrate solution. The reaction was stopped by boiling for $10 \mathrm{~min}$ at $90^{\circ} \mathrm{C}$. The samples were then spun for $5 \mathrm{~min}$ at $10,000 \mathrm{rpm}$. The fluorescence of the supernatants was measured at an emission wavelength of $562 \mathrm{~nm}$ and an excitation wavelength of $342 \mathrm{~nm}$. The NEP activity was calculated as a difference in fluorescence between samples incubated with and without phosphoramidon, and expressed as relative fluorescence units.

\section{Statistical Analysis}

The data were analyzed using SPSS 14.0 (SPSS Inc., Chicago, Ill., USA). Differences between the means were assessed by Student's t test or 1-way ANOVA followed by Fisher's LSD or Tukey's post-hoc tests. Correlation studies were performed by parametric correlation and linear regression analysis. The null hypothesis was rejected at the 0.05 level.

\section{Results}

\section{Absence of RAGE Reduced the Amount of Insoluble} $A \beta$ in 6-Month-Old ArcA $\beta$ Mice

In order to evaluate the influence of $R A G E$ deletion (online suppl. fig. 1) on $A \beta$ deposition, we examined the $A \beta$ peptide levels in the brain regions relevant to cognition, i.e. the hippocampus and cortex. The $A \beta$ levels were assessed with respect to the extraction conditions and the variant length (A $\beta 40$ and $A \beta 42)$ using Western blot and C-terminus-specific ELISA. The brains were extracted sequentially in $1 \%$ Triton X-100, $2 \%$ SDS and $70 \%$ FA, to allow for the isolation of $\mathrm{A} \beta$ species that differ in the aggregation state and cellular/extracellular localization, with SDS-extractable $A \beta$ pertaining to the membraneenriched fraction and FA-extractable (insoluble) A $\beta$ representing extracellular amyloid. Both the Western blot and ELISA approaches indicated significantly lower overall levels of accumulated $A \beta$ in the cortex and hippocampus at the age of 6 months in $\mathrm{RAGE}^{-/-} / \operatorname{arcA} \beta$ animals compared to arcA $\beta$ mice with normal RAGE expression. Interestingly, the difference was due to the low $A \beta$ levels extracted into SDS and FA, but not caused by Triton X100-requiring peptide (tables 1 and 2). Despite the clear differences in the amount of extractable $A \beta$ found by biochemical methods, histological analysis did not reveal any difference in $A \beta$-occupied brain areas at 6 months (fig. 1a), possibly due to the fact that at this age, visible plaque formation has not yet started in $\operatorname{arc} A \beta$ mice [2]. At the age of 12 months, when $A \beta$ deposition has progressed much more, biochemical and histopathological approaches revealed no more difference in the total $A \beta$ load, nor $A \beta 40$ and $A \beta 42$ variants, in any of the fractions between $\mathrm{RAGE}^{-1-} / \operatorname{arcA} \beta$ and $\operatorname{arcA} \beta$ mice (tables 1 and 2 ; fig. $1 b)$. However, the $A \beta 40$ level was significantly decreased in the serum of $\mathrm{RAGE}^{-/-} / \operatorname{arcA} \beta$ animals.

Given the possibility that the genetic manipulation might not only influence $A \beta$ deposition and quantities but also morphological features of deposits, we examined both plaques and CAA but found no structural differences between $\mathrm{RAGE}^{-/-} \operatorname{arcA} \beta$ and $\operatorname{arcA} \beta$ mice (fig. 2 and 3). Plaques in $\mathrm{RAGE}^{-/-} / \operatorname{arcA} \beta$ animals, detected at 12 months (fig. 3a, g), had the same dense-core morphology as $\operatorname{arc} A \beta$ mice (fig. $3 b, d, h, j$ ) and were also accompanied by severe CAA (fig. $3 c$, i).

\section{RAGE Did Not Influence APP Expression and \\ Processing}

To determine whether the decreased amount of $A \beta$ could be due to altered APP expression or processing 
Table 1. $A \beta$ levels measured by ELISA specific for $A \beta x-40$ and $A \beta x-42$

\begin{tabular}{|c|c|c|c|c|c|c|c|c|}
\hline \multirow{2}{*}{$\begin{array}{l}\text { Age } \\
\text { months }\end{array}$} & \multirow{2}{*}{ Genotype } & \multirow[t]{2}{*}{$A \beta$} & \multicolumn{3}{|l|}{ Cortex } & \multicolumn{2}{|l|}{ Hippocampus } & \multirow{2}{*}{$\begin{array}{l}\text { Serum } \\
\mathrm{pg} / \mathrm{ml}\end{array}$} \\
\hline & & & $\begin{array}{l}1 \% \text { Triton } \\
\mathrm{ng} / \mathrm{ml}\end{array}$ & $\begin{array}{l}2 \% \text { SDS } \\
\mathrm{ng} / \mathrm{ml}\end{array}$ & $\begin{array}{l}\text { 70\% FA } \\
\mathrm{ng} / \mathrm{ml}\end{array}$ & $\begin{array}{l}1 \% \text { Triton, } \\
2 \% \text { SDS, ng/ml }\end{array}$ & $\begin{array}{l}70 \% \mathrm{FA} \\
\mathrm{ng} / \mathrm{ml}\end{array}$ & \\
\hline \multirow[t]{4}{*}{6} & \multirow[t]{2}{*}{$\mathrm{RAGE}^{-/-} / \operatorname{arcA} \beta$} & $\mathrm{A} \beta 40$ & $4.52 \pm 0.02$ & $4.62 \pm 0.09$ & $1.59 \pm 0.48^{*}$ & $3.47 \pm 0.13$ & ND & ND \\
\hline & & $\mathrm{A} \beta 42$ & $6.37 \pm 0.10$ & $4.59 \pm 0.13^{*}$ & $1.30 \pm 0.50^{*}$ & $2.24 \pm 0.04$ & ND & ND \\
\hline & \multirow[t]{2}{*}{$\operatorname{arcA} \beta$} & $\mathrm{A} \beta 40$ & $4.61 \pm 0.03$ & $6.02 \pm 0.62$ & $11.34 \pm 3.53$ & $3.56 \pm 0.21$ & ND & ND \\
\hline & & $\mathrm{A} \beta 42$ & $6.68 \pm 0.15$ & $6.88 \pm 0.87$ & $6.52 \pm 2.02$ & $1.76 \pm 0.33$ & ND & ND \\
\hline \multirow[t]{4}{*}{12} & \multirow[t]{2}{*}{$\mathrm{RAGE}^{-/-} / \operatorname{arcA} \beta$} & $\mathrm{A} \beta 40$ & $27.73 \pm 8.93$ & $143.48 \pm 41.50$ & $380.48 \pm 111.04$ & $20.38 \pm 4.33$ & $65.18 \pm 18.37$ & $258.51 \pm 32.12^{*}$ \\
\hline & & $\mathrm{A} \beta 42$ & $5.92 \pm 1.07$ & $50.14 \pm 6.49$ & $101.47 \pm 42.07$ & $5.56 \pm 0.65$ & $25.27 \pm 5.35$ & ND \\
\hline & \multirow[t]{2}{*}{$\operatorname{arcA} \beta$} & $\mathrm{A} \beta 40$ & $15.71 \pm 8.83$ & $62.41 \pm 12.58$ & $402.39 \pm 140.74$ & $11.80 \pm 2.88$ & $96.35 \pm 33.93$ & $432.70 \pm 59.93$ \\
\hline & & $\mathrm{A} \beta 42$ & $4.01 \pm 1.19$ & $44.38 \pm 5.90$ & $97.64 \pm 33.33$ & $5.29 \pm 0.92$ & $36.13 \pm 10.80$ & ND \\
\hline
\end{tabular}

Values are means $\pm \mathrm{SE} . \mathrm{ND}=$ Not detectable. ${ }^{*} \mathrm{p}<0.05$

Table 2. Monomeric A $\beta$ levels determined by densitometric analysis of Western blot assay with $6 \mathrm{E} 10$ antibody

\begin{tabular}{|c|c|c|c|c|c|c|}
\hline \multirow{2}{*}{$\begin{array}{l}\text { Age } \\
\text { months }\end{array}$} & \multirow[t]{2}{*}{ Genotype } & \multicolumn{3}{|l|}{ Cortex } & \multicolumn{2}{|l|}{ Hippocampus } \\
\hline & & $1 \%$ Triton & $2 \% \mathrm{SDS}$ & $70 \% \mathrm{FA}$ & $1 \%$ Triton, $2 \%$ SDS & $70 \% \mathrm{FA}$ \\
\hline \multirow[t]{2}{*}{6} & $\mathrm{RAGE}^{-/-} / \operatorname{arcA} \beta$ & $96.0 \pm 32.5$ & $10.3 \pm 3.7^{* *}$ & $7.7 \pm 3.9^{* * *}$ & $67.0 \pm 23.2$ & $3.36 \pm 1.8^{*}$ \\
\hline & $\operatorname{arcA} \beta$ & $100.0 \pm 6.5$ & $100.0 \pm 35.0$ & $100.0 \pm 23.1$ & $100.0 \pm 30.1$ & $100.0 \pm 55.3$ \\
\hline \multirow[t]{2}{*}{12} & $\mathrm{RAGE}^{-/-} / \operatorname{arcA} \beta$ & $222.1 \pm 88.8$ & $164.7 \pm 48.6$ & $101.6 \pm 24.7$ & $76.2 \pm 18.9$ & $83.6 \pm 25.7$ \\
\hline & $\operatorname{arcA} \beta$ & $100.0 \pm 33.0$ & $100.0 \pm 12.4$ & $100.0 \pm 18.3$ & $100.0 \pm 15.7$ & $100.0 \pm 20.5$ \\
\hline
\end{tabular}

Data are mean relative intensity $\pm \mathrm{SE} .{ }^{*} \mathrm{p}<0.05 ;{ }^{* *} \mathrm{p}<0.01 ;{ }^{* *} \mathrm{p}<0.001$.

caused by the absence of RAGE, we examined the levels of full-length APP (APP), soluble APP (sAPP) as well as C-terminal fragments produced by $\beta$-secretase (CTF- $\beta$ ) by Western blot using 6E10, 22C11 and anti-APP C-terminal antibodies. There was no difference in APP, sAPP and CTF- $\beta$ levels according to the densitometric analysis of immunoblots upon normalization to $\beta$-tubulin in the cortex and the hippocampus between the 2 transgenic groups (fig. 4).

\section{$R A G E^{-/-} /$Arc A $\beta$ Mice Showed Increased \\ $A \beta$-Degrading Enzymatic Activity}

Our finding that the cerebral levels of SDS- and FAsoluble $A \beta$ were reduced in the brains of 6 -month-old mice without any change in APP processing suggested that the activity of 1 or more $A \beta$-degrading proteases might be increased. To test this hypothesis, we examined the enzymatic activity of 3 proteases in the cortices of 6 and 12-month-old animals. Analysis of IDE activity re- vealed significant main effects of the APP transgene $[\mathrm{F}(1,16)=28.218, \mathrm{p}=0.001]$ and of the RAGE knockout condition $[\mathrm{F}(1,16)=37.102$, $\mathrm{p}<0.001]$, with no interaction, indicating their additive effect. At the age of 6 months, IDE in $\mathrm{RAGE}^{-/-} / \operatorname{arcA} \beta$ had a significantly higher activity than in $\operatorname{arc} \mathrm{A} \beta$ mice $(\mathrm{p}=0.05), \mathrm{RAGE}^{-/-}$mice $(\mathrm{p}=0.11)$ and wild-type animals $(\mathrm{p}<0.001$; fig. 5a). However, at the age of 12 months the difference between $\mathrm{RAGE}^{-/-} / \operatorname{arcA} \beta$ and $\operatorname{arcA} \beta$ was not statistically significant; $\mathrm{RAGE}^{-/-} / \operatorname{arcA} \beta$ animals had an increased activity of the enzyme only in comparison with the wild-type animals $(\mathrm{p}=0.043)$. There was no significant difference in the activity of 2 other $A \beta$-degrading enzymes, $A C E$ and neprilysin, among the 4 groups (fig. $5 b, c$ ).

\section{Absence of RAGE Did Not Ameliorate Cognitive Impairment}

To clarify whether the reduced amount of $A \beta$ in $\mathrm{RAGE}^{-/-} / \operatorname{arcA} \beta$ mice at 6 months would result in less se- 
Fig. 1. Percentage of brain areas occupied by $A \beta$ deposits, detected by thioflavin $S$ (ThioS) and 6E10 staining, at the age of 6 (a) and 12 (b) months. There was no statistically significant difference between the 2 APP transgene-bearing groups. a No thioflavin-S-positive deposits were detected in the hippocampus at the age of 6 months. Values are means $\pm S E, n=8-9$ mice per group. CTX = Cortex; HIPP = hippocampus.

Fig. 2. The lack of RAGE does not change $A \beta$ deposition at the age of 6 months. In the overview of cortical sections of 6 month-old $\mathrm{RAGE}^{-/-} / \operatorname{arcA} \beta$ (a) and $\operatorname{arcA} \beta$ (b) mice there were no plaques or CAA detected, just a few 6E10-stained (green) $\mathrm{A} \beta$ deposits that started to attract microglia (Iba1; red), as visible in (c) and (d) with enlarged details from the overview images. Scale bar: $100 \mu \mathrm{m}(\mathbf{a}, \mathbf{b}) ; 50 \mu \mathrm{m}(\mathbf{c}, \mathbf{d})$.
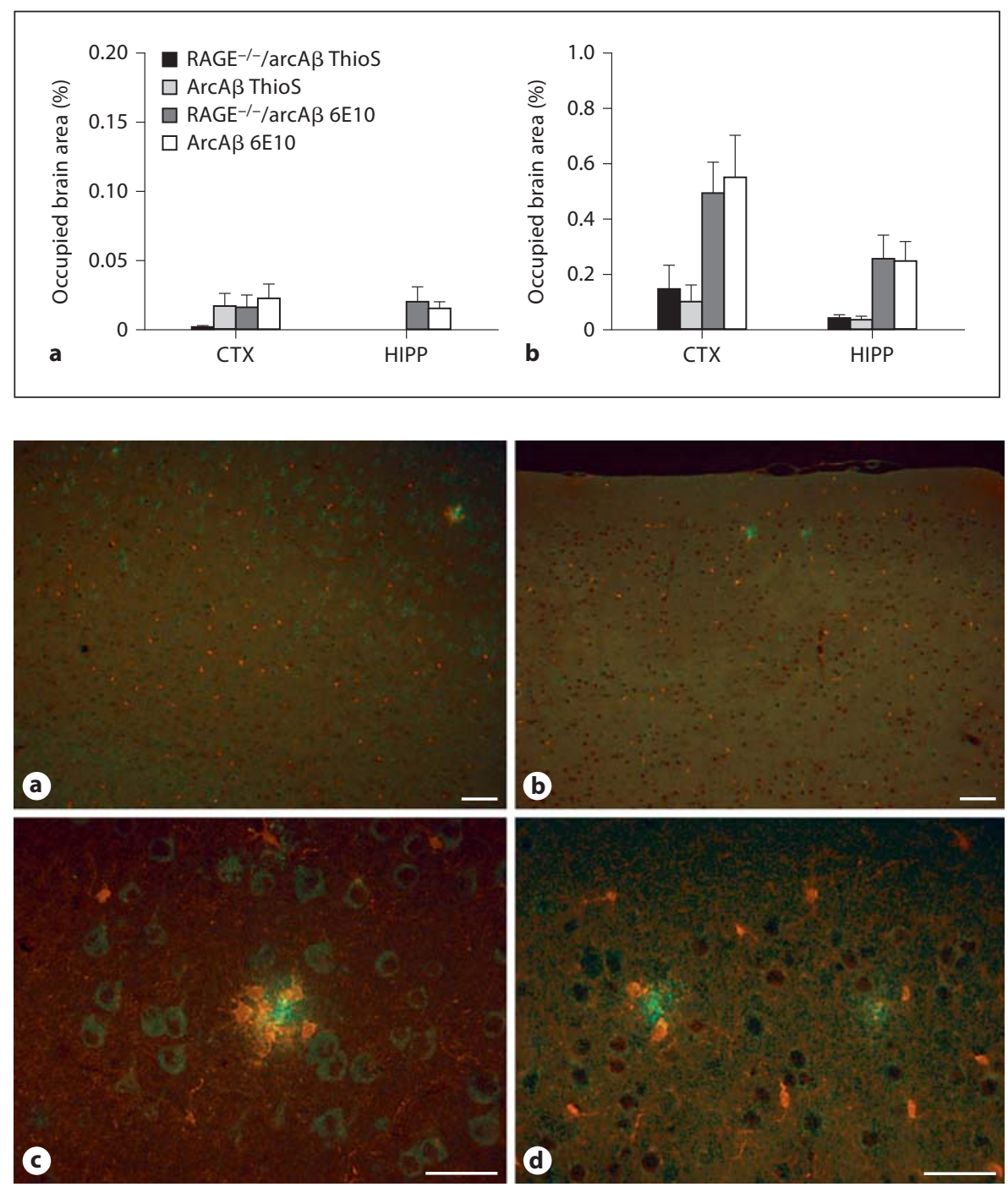

vere cognitive deficits that had previously been described in $\operatorname{arc} A \beta$ mice, the different genotype groups were tested in the Y maze, a working memory test. There was no significant difference in $\mathrm{Y}$ maze performance between the $\mathrm{RAGE}^{-/-} / \operatorname{arc} \mathrm{A} \beta$ and $\operatorname{arcA} \beta$ animal groups at the age of 6 and 12 months. Although they had less SDS- and FAsoluble $A \beta$ load at 6 months, the $\mathrm{RAGE}^{-/-} / \operatorname{arcA} \beta$ mice had the same extent of cognitive deficits as the $\operatorname{arc} A \beta$ animals. This impairment was not due to the lack of RAGE, since the $\mathrm{RAGE}^{-/}$mice performed equally well as the wild-type animals (fig. 6).

\section{Cognitive Impairment Correlated with}

Triton-X-Extractable $A \beta$

Given the cognitive deficits in the animals harboring the APP transgene, we evaluated whether the extent of ac- cumulated $A \beta$ was related to the degree of cognitive performance in individual mice. There was a significant negative correlation between the percent alternation in the $\mathrm{Y}$ maze and monomeric $A \beta$ cortical levels present in $1 \%$ Triton X-100 fraction determined by densitometric analysis of Western blot with $6 \mathrm{E} 10$ antibody but not with the $\mathrm{A} \beta$ levels in other fractions or in the hippocampus. Additionally, there was no significant correlation between Y-maze performance and the levels of 2 length variants, $A \beta 40$ or $A \beta 42$. The association between soluble $A \beta$ load in the cortical area and working memory impairment was significant at the age of 6 months for both $\mathrm{RAGE}^{-/-} / \operatorname{arcA} \beta(\mathrm{p}=0.0146)$ and $\operatorname{arc} A \beta$ mice $(p=0.043)$ (fig. $7 a)$, and the $r$ values obtained for the 2 groups were not significantly different. At 12 months of age, the negative correlation was only significant for the $\mathrm{RAGE}^{-/-} / \operatorname{arcA} \beta$ mice $(\mathrm{p}=0.020$; fig. $7 \mathrm{~b})$. 

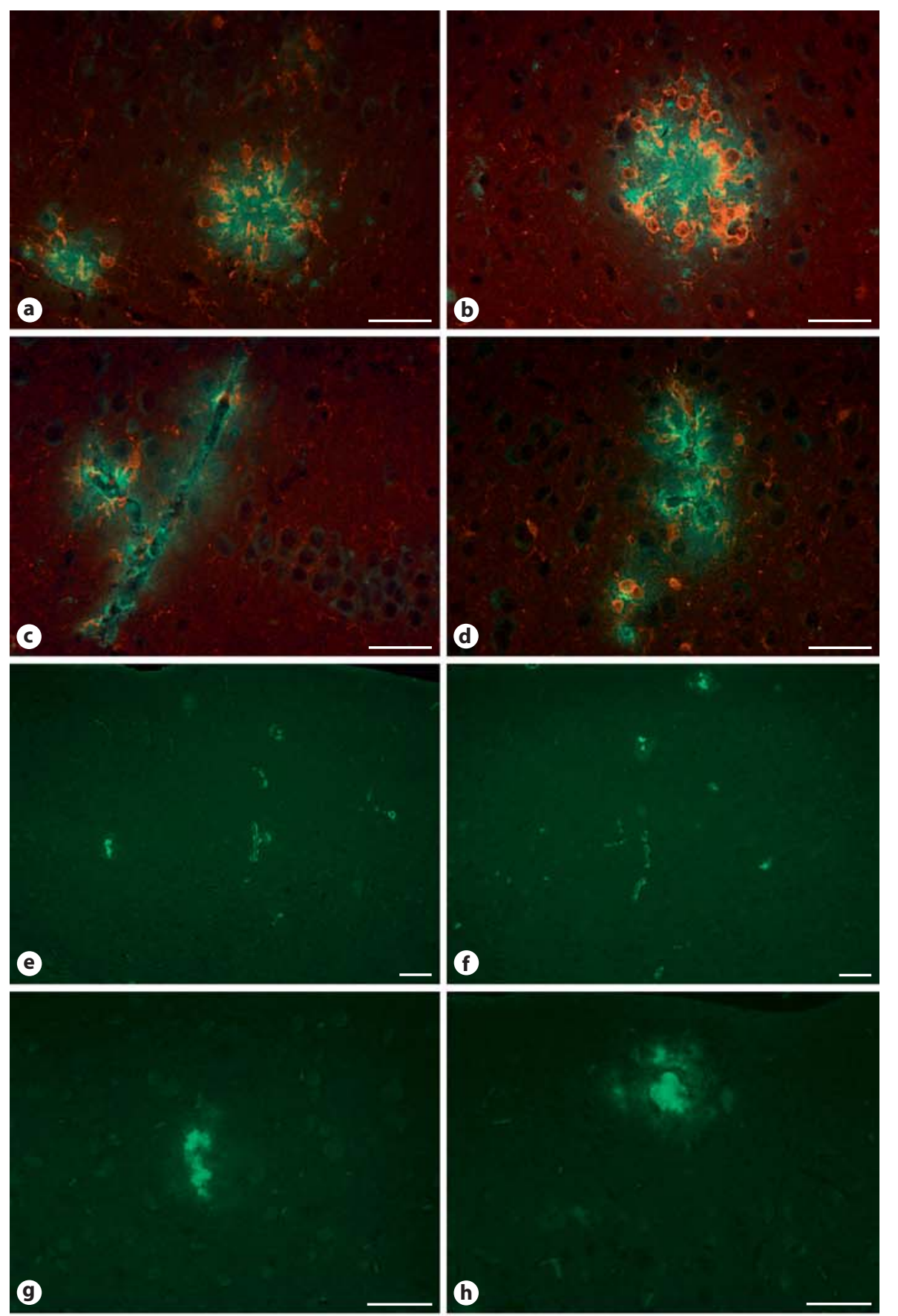

Fig. 3. Plaque dense-core morphology and CAA at 12 months in the cortex and hippocampus of $\mathrm{RAGE}^{-/-} / \operatorname{arcA} \beta(\mathbf{a}, \mathbf{c}, \mathbf{e}, \mathbf{g}, \mathbf{i})$ and $\operatorname{arcA} \beta(\mathbf{b}, \mathbf{d}, \mathbf{f}, \mathbf{h}, \mathbf{j})$. a-d 6E10 staining (green), paralleled with the Ibal staining of microglia [31], revealing plaque morphology (a, b) and CAA (c, d). e-j Thioflavin-S-stained overview images of mouse cortices $(\mathbf{e}, \mathbf{f})$ and their respective enlarged details demonstrating dense-core plaques $(\mathbf{g}, \mathbf{h})$ and CAA $(\mathbf{i}, \mathbf{j})$. Scale bar: $100 \mu \mathrm{m}(\mathbf{e}$, f); $50 \mu \mathrm{m}(\mathbf{a}-\mathbf{d}, \mathbf{g}-\mathbf{j})$.
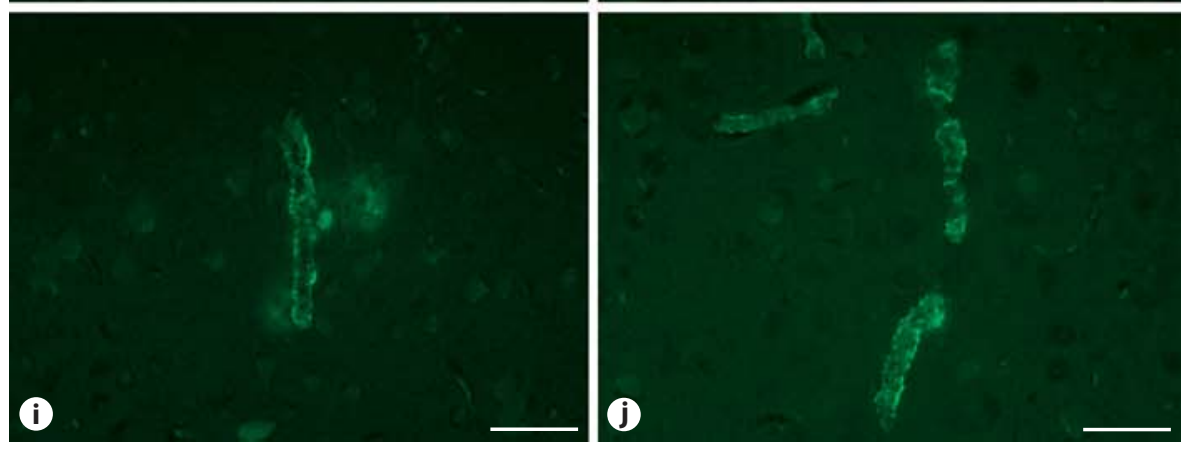


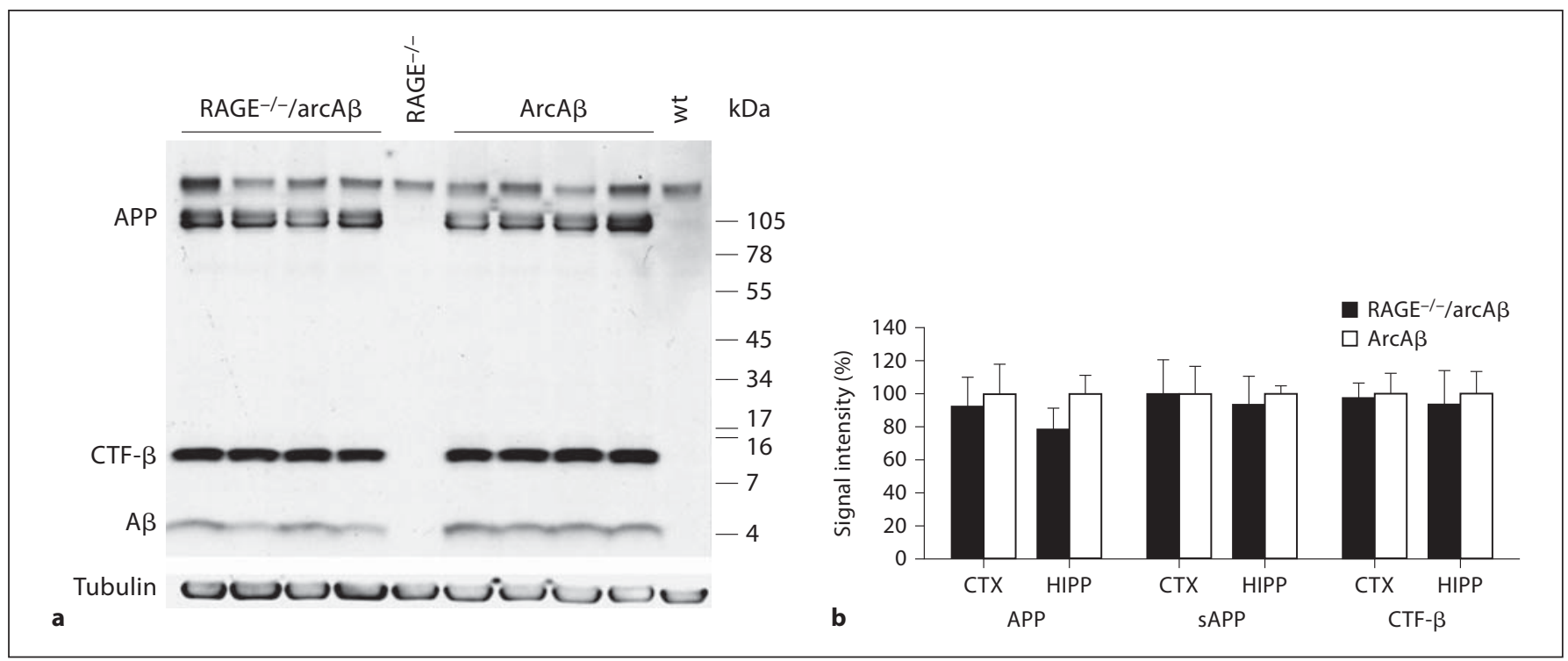

Fig. 4. Western-blot-based characterization of APP, sAPP $\alpha$ and CTFs in 6- and 12-month-old $\mathrm{RAGE}^{-/-} / \mathrm{arcA} \beta$ mice. a Representative 6 E10 immunoblot from $1 \%$ Triton X-100 cerebral cortex homogenates from 6-month-old animals. b Densitometric analysis of APP, sAPP and CTF- $\beta$ signal intensities in 6E10, 22C11 and
APP C-terminal immunoblots, respectively, normalized to $\beta$-tubulin. Each value represents the mean \pm SE of 8-9 six-month-old mice for each brain region analyzed. CTX = Cortex; HIPP = hippocampus; $w \mathrm{t}=$ wild type.

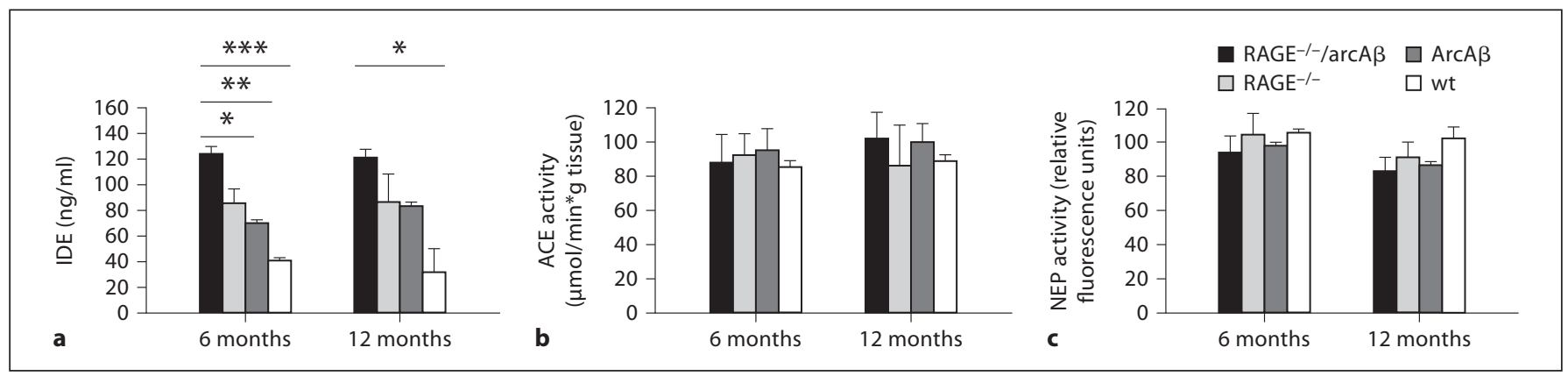

Fig. 5. Enzyme activity measurements in crude cortical homogenates. a IDE activity was significantly increased in the $\mathrm{RAGE}^{-/-}$/ $\operatorname{arcA} \beta$ cortices at the age of 6 months in comparison with the 3 other genotypes. $\mathbf{b}$ There was no difference in ACE activity among the animal groups. c No difference was detected in neprilysin activity among the different genotypes. Values are means $\pm \mathrm{SE}$, $\mathrm{n}=8-9$ mice per group. ${ }^{*} \mathrm{p}<0.05 ;{ }^{* *} \mathrm{p}<0.01 ;{ }^{* *} \mathrm{p}<0.001$ : 1 -way ANOVA followed by Tukey's post-hoc analysis. wt $=$ Wild type.
Fig. 6. Behavioral performance in the $\mathrm{Y}$ maze, a working memory test measuring spontaneous alternation behavior, at the age of 6 (a) and 12 (b) months. RAGE ${ }^{-/-}$ $\operatorname{arcA} \beta$ had impaired working memory in comparison to control animals already at the age of 6 months. Values are means \pm $\mathrm{SE}, \mathrm{n}=8-9$ mice per group. ${ }^{*} \mathrm{p}<0.05$; ${ }^{* *} \mathrm{p}<0.01$ : 1-way ANOVA followed by Fisher's LSD post-hoc analysis. wt $=$ Wild type.

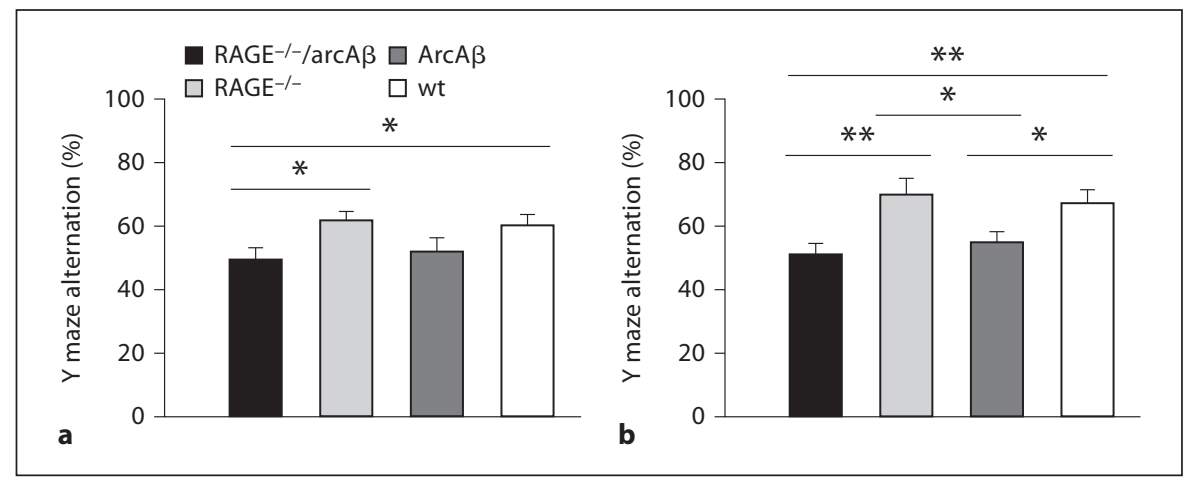




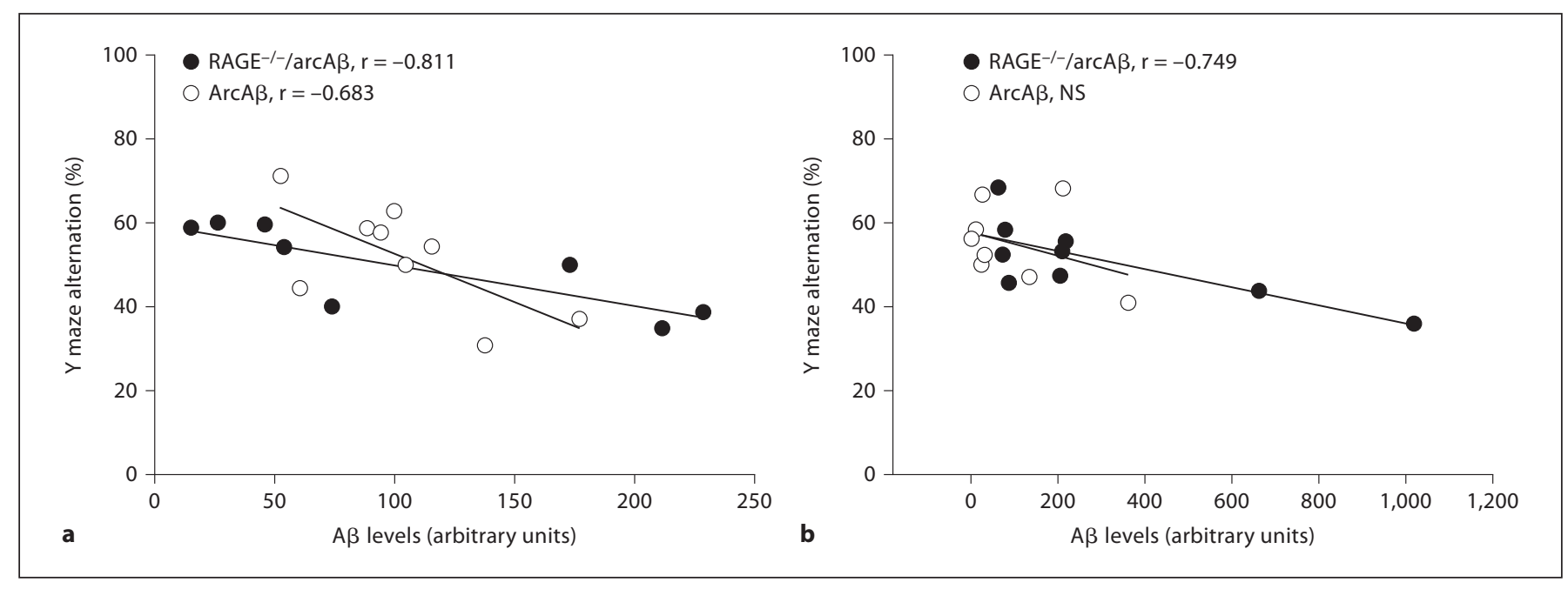

Fig. 7. Inverse correlation between $Y$ maze performance and $A \beta$ cortical levels present in $1 \%$ Triton X-100 fraction determined by densitometric analysis of 6E10 immunoblot. a At 6 months, the levels of soluble monomeric $A \beta$ in the cortical fraction were sig- nificantly negatively correlated with the percent alternation in the $\mathrm{Y}$ maze in both $\mathrm{RAGE}^{-/-} / \operatorname{arcA} \beta(\mathrm{p}=0.0146)$ and $\operatorname{arcA} \beta$ mice $(\mathrm{p}=$ $0.043)$. b At 12 months of age the negative correlation was significant only for the $\mathrm{RAGE}^{-/-} / \operatorname{arcA} \beta$ mice $(\mathrm{p}=0.020)$.
Lack of RAGE Did Not Alter the Amount of Microglia

No difference in the microglia-occupied brain area or microglial morphology was observed in $\mathrm{RAGE}^{-/}$mice in comparison to wild-type animals at both examined ages (fig. 8c, d). Also, these animals did not differ from $\mathrm{RAGE}^{-1-} / \operatorname{arcA} \beta$ and $\operatorname{arcA} \beta$ mice with respect to the microglia-occupied brain area at the age of 6 months, when no dense-core plaques or CAA can be demonstrated yet (fig. 8a). At 12 months, there was a significant equal increase in Ibal-occupied brain area in both $\mathrm{RAGE}^{-/-}$ $/ \operatorname{arcA} \beta$ and $\operatorname{arcA} \beta$ mice when compared to APP nontransgenic animals (fig. 8b), due to the formation of plaques and CAA that attract microglia (fig. $4 a-d$ ).

\section{Discussion}

Several lines of evidence suggested a role of the RAGE receptor in $\mathrm{AD}$ pathogenesis with different underlying processes proposed. Studies in mice and cell culture indicated that RAGE promotes $A \beta$ accumulation through 2 different mechanisms. First, RAGE is thought to mediate $A \beta$ peptide influx into the central nervous system through the blood-brain barrier [7, 8], thus increasing the amount of $A \beta$ in the brain. The second mechanism leading to enhanced $A \beta$ accumulation via RAGE proposes a direct stimulation of BACE1 expression, the secretase involved in $A \beta$ production [9]. In addition, RAGE is as- sumed to promote $\mathrm{AD}$ pathology by activating microglia, with subsequent induction of chemotaxis, cell proliferation, as well as ROS and cytokine production $[1,10,11]$. To better understand the in vivo role of RAGE in AD pathology, we generated and characterized $\operatorname{arcA} \beta$ mice lacking RAGE. These animals had an increased IDE activity during the first 6 months of life and were protected from $A \beta$ accumulation only to a certain extent. There were lower levels of $A \beta$ extractable by SDS and FA (insoluble $A \beta$ ) in the brains of $\mathrm{RAGE}^{-/-} / \operatorname{arcA} \beta$ mice at the age of 6 months, but this effect disappeared by the age of 12 months, most probably due to the constant peptide production overwhelming the clearance process. In addition, the observed IDE upregulation resulted from an additive effect of RAGE deletion and the APP transgene or probably $A \beta$ accumulation, as previously suggested [12, 13]. Although it presumably decreased initial $A \beta$ buildup, the IDE-mediated clearance process did not prevent cognitive decline and eventually became inefficient at the age of 12 months given the similar amounts of cerebral $A \beta$ in both genotypes. Arc $A \beta$ mice have been previously shown to generate $A \beta$ only in the nervous system [2], thus precluding the relevance of external $A \beta$ influx into the brain to the development of brain pathology in this mouse model. In addition, our study showed significantly lower serum levels of $A \beta 40$ in $\mathrm{RAGE}^{-/} / \operatorname{arcA} \beta$ mice than in the $\operatorname{arcA} \beta$ animals at the age of 12 months, contradicting the possible relevance of $A \beta$ transport across the blood-brain 


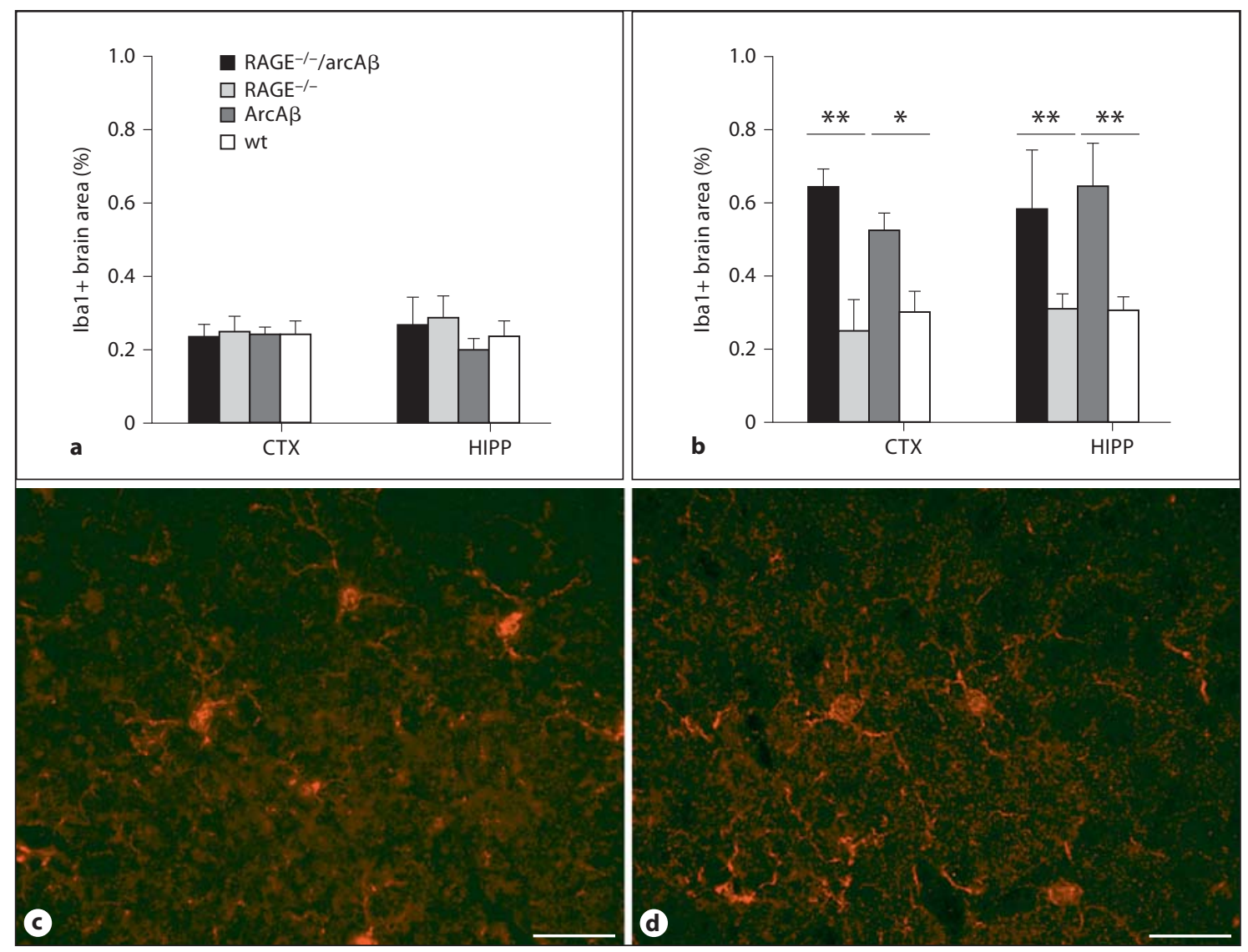

Fig. 8. Percentage of brain areas occupied by microglia (Iba1+ cells) at the age of 6 (a) and 12 (b) months. The significant increase in both $\mathrm{RAGE}^{-/-} / \operatorname{arcA} \beta$ mice and $\operatorname{arcA} \beta$ observed at 12 months of age was associated with the plaque accumulation. Values are means \pm SE, $n=8-9$ mice per group. There was no difference in the microglia-occupied brain area or microglial morphology between $\mathrm{RAGE}^{-1-}$ (12 months; c) and wt (12 months; d) animals. Scale bar: $30 \mu \mathrm{m}$. CTX = Cortex; HIPP = hippocampus; $w \mathrm{t}=$ wild type. ${ }^{*} \mathrm{p}<0.01,{ }^{* *} \mathrm{p}<0.001$ : 1-way ANOVA followed by Tukey's post-hoc analysis. barrier for cerebral $A \beta$ accumulation. RAGE involvement in APP processing via BACE did not seem to be plausible in the $\operatorname{arcA} \beta$ mice either given the identical levels of CTF- $\beta$ observed in both genotypes. Similarly, our study did not reveal any change in microglia number or morphology in animals lacking RAGE. The RAGE ${ }^{-/-}$/ $\operatorname{arcA} \beta$ mice had comparable brain areas occupied by microglia in both age groups. Additionally, there was a marked activation of microglia evident in parallel with the onset of fibrillar plaques in both genotypes, which would not favor an in vivo role of RAGE to promote microglia activation in $\mathrm{AD}$ either. This is in agreement with the previous findings in APP23 mice, whereby the majority of activated microglia, present in the vicinity of amyloid plaques, did not upregulate RAGE expression [14].

Differences observed between previous studies and the results presented here may be explained by confound- ing factors not accounted for in previously applied experimental settings, methodologies and animal models. These include APP transgenic mice overexpressing RAGE or bearing dominant-negative RAGE (DN-RAGE), DNRAGE and wild-type mice injected or infused with $A \beta$, as well as APP transgenic or A $\beta$-infused mice which were treated with truncated, soluble form of RAGE, sRAGE [7, $15,16]$. Remarkably, sRAGE-treated animals show greater protection compared to RAGE-null $\left(\mathrm{RAGE}^{-/-}\right)$animals against deleterious effects of inflammation [17], diabetic nephropathy and concomitant VEGF expression [18], or diabetic neuropathy [19], conditions in which RAGE is suggested to be a key pathology-mediating molecule. In addition, exogenous sRAGE blocks inflammation even in $\mathrm{RAGE}^{-/-}$animals [17], which altogether suggests involvement of sRAGE in additional pathways linked to inflammatory response. Endogenous sRAGE is 
produced by alternative splicing of the RAGE mRNA as well as by proteolytic cleavage $[20,21]$. According to the studies conducted with exogenous sRAGE, endogenous sRAGE was supposed to play an antagonistic role by competing with cell surface RAGE, thus inhibiting RAGEinduced signaling $[7,17,22]$. The physiologic concentrations of circulating sRAGE, found in diabetic patients, are much lower than required to scavenge accumulating ligands [23]. It is, however, possible that RAGE and DNRAGE overexpression [15] leads to increased levels of sRAGE with protective properties. Additionally, mechanisms accounting for the absence of pathological effects in APP mice expressing DN-RAGE could be similar to the more overt protection observed in DN-RAGE mice compared to $\mathrm{RAGE}^{-/-}$animals in the context of atherosclerosis [24].

No reduction in $A \beta$ levels was observed in Triton X100 brain extract, the only $A \beta$ fraction correlating with $Y$ maze performance. Such a correlation is in line with the previous $\mathrm{AD}$ research pointing to the causative role of $\mathrm{A} \beta$ oligomers present in the soluble brain extracts $[25,26]$. At the age of 12 months, when the $A \beta$ load increased in all fractions in both genotypes, such a correlation was not detected in arcA $\beta$ mice, possibly because of different susceptibility to soluble $A \beta$ in this group of animals. The same extent of cognitive impairment observed in $\mathrm{RAGE}^{-/-} / \operatorname{arcA} \beta$ mice as in $\operatorname{arcA} \beta$ mice is also challenging the hypothesis about RAGE contribution to brain $\mathrm{A} \beta$-related pathophysiology. This is consistent with the recent study investigating a relationship between the psychomotor or cognitive performance and amounts of RAGE increasing with age in several brain regions which failed to detect any association between the variables [27]. Moreover, in the same study there was no correlation be- tween the age-related accumulation of advanced glycation end products, which are major RAGE ligands, and RAGE expression in the mouse brain. Another report about enhanced $A \beta$ deposition in the mouse brain did not find any parallel significant change in RAGE expression [28].

The observed significant upregulation of IDE in $\mathrm{RAGE}^{-1-} / \operatorname{arcA} \beta$ mice at the age of 6 months suggested that IDE expression and RAGE signaling function are associated. The underlying network linking the 2 molecules has not been unraveled. Recently, it has been described that while the 'anti-inflammatory' cytokines IL-4 and IL-13 increase IDE expression [29], 'pro-inflammatory' IFN- $\gamma$ and TNF- $\alpha$ have an opposite effect [30]. Deletion of RAGE and removal of its proinflammatory influence may thus push the balance towards the anti-inflammatory pathways and promote IDE expression. In conclusion, a general contribution of RAGE to microglial activation, $A \beta$ intracerebral accumulation or cognitive impairment in the $\operatorname{arc} A \beta$ mice seems to be unlikely. The initial increase in IDE activity, however, along with the reduced brain $A \beta$ levels during the initial 6 months of life may permit an unexpected role of RAGE in regulating $\mathrm{A} \beta$ proteolysis.

\section{Acknowledgements}

We would like to thank Jay Tracy for expert technical support. We are grateful to Barbara Biscaro and Mario Merlini for encrypting the mice, scientific advice and assistance with histochemical studies. This work was supported by the Swiss National Center for Competence in Research (NCCR) on 'Neural Plasticity and Repair' and by the Swiss National Foundation Grant 3200B$112626 / 1$.

\section{References}

1 Yan SD, Chen X, Fu J, Chen M, Zhu H, Roher A, Slattery T, Zhao L, Nagashima M, Morser J, Migheli A, Nawroth P, Stern D, Schmidt AM: Rage and amyloid- $\beta$ peptide neurotoxicity in Alzheimer's disease. Nature 1996; 382:685-691.

- 2 Knobloch M, Konietzko U, Krebs DC, Nitsch $\mathrm{RM}$ : Intracellular $A \beta$ and cognitive deficits precede $\beta$-amyloid deposition in transgenic $\operatorname{arcA} \beta$ mice. Neurobiol Aging 2007;28:12971306.
3 Constien R, Forde A, Liliensiek B, Grone HJ, Nawroth P, Hammerling G, Arnold B: Characterization of a novel EGFP reporter mouse to monitor cre recombination as demonstrated by a Tie2 Cre mouse line. Genesis 2001;30:36-44.

-4 Ostendorp T, Weibel M, Leclerc E, Kleinert P, Kroneck PM, Heizmann CW, Fritz G: Expression and purification of the soluble isoform of human receptor for advanced glycation end products (sRAGE) from Pichia Pastoris. Biochem Biophys Res Commun 2006;347:4-11.
Carpenter TC, Stenmark KR: Hypoxia decreases lung neprilysin expression and increases pulmonary vascular leak. Am J Physiol Lung Cell Mol Physiol 2001;281: L941-L948.

-6 Carter TL, Pedrini S, Ghiso J, Ehrlich ME, Gandy S: Brain neprilysin activity and susceptibility to transgene-induced Alzheimer amyloidosis. Neurosci Lett 2006;392:235239. 
7 Deane R, Du Yan S, Submamaryan RK, LaRue B, Jovanovic S, Hogg E, Welch D, Manness L, Lin C, Yu J, Zhu H, Ghiso J, Frangione B, Stern A, Schmidt AM, Armstrong DL, Arnold B, Liliensiek B, Nawroth P, Hofman F, Kindy M, Stern D, Zlokovic B: Rage mediates a myloid- $\beta$ peptide transport across the blood-brain barrier and accumulation in brain. Nat Med 2003;9:907-913.

>8 Mackic JB, Stins M, McComb JG, Calero M, Ghiso J, Kim KS, Yan SD, Stern D, Schmidt AM, Frangione B, Zlokovic BV: Human blood-brain barrier receptors for Alzheimer's amyloid- $\beta$ 1-40: asymmetrical binding, endocytosis, and transcytosis at the apical side of brain microvascular endothelial cell monolayer. J Clin Invest 1998;102:734743.

-9 Cho HJ, Son SM, Jin SM, Hong HS, Shin DH, Kim SJ, Huh K, Mook-Jung I: Rage regulates BACE1 and $A \beta$ generation via NFAT1 activation in Alzheimer's disease animal model. FASEB J 2009;23:2639-2649.

-10 Lue LF, Walker DG, Brachova L, Beach TG, Rogers J, Schmidt AM, Stern DM, Yan SD: Involvement of microglial receptor for advanced glycation endproducts (RAGE) in Alzheimer's disease: identification of a cellular activation mechanism. Exp Neurol 2001;171:29-45.

-11 Du Yan S, Zhu H, Fu J, Yan SF, Roher A, Tourtellotte WW, Rajavashisth T, Chen X, Godman GC, Stern D, Schmidt AM: Amyloid- $\beta$ peptide receptor for advanced glycation endproduct interaction elicits neuronal expression of macrophage colony-stimulating factor: a proinflammatory pathway in Alzheimer disease. Proc Natl Acad Sci USA 1997;94:5296-5301.

-12 Leal MC, Dorfman VB, Gamba AF, Frangione B, Wisniewski T, Castano EM, Sigurdsson EM, Morelli L: Plaque-associated overexpression of insulin-degrading enzyme in the cerebral cortex of aged transgenic tg2576 mice with Alzheimer pathology. J Neuropathol Exp Neurol 2006;65:976-987.

-13 Vepsalainen S, Hiltunen M, Helisalmi S, Wang J, van Groen T, Tanila H, Soininen H: Increased expression of $A \beta$ degrading enzyme IDE in the cortex of transgenic mice with Alzheimer's disease-like neuropathology. Neurosci Lett 2008;438:216-220.

14 Bornemann KD, Wiederhold KH, Pauli C, Ermini F, Stalder M, Schnell L, Sommer B, Jucker M, Staufenbiel M: A $\beta$-induced inflammatory processes in microglia cells of APP23 transgenic mice. Am J Pathol 2001; 158:63-73.
15 Arancio O, Zhang HP, Chen X, Lin C, Trinchese F, Puzzo D, Liu S, Hegde A, Yan SF, Stern A, Luddy JS, Lue LF, Walker DG, Roher A, Buttini M, Mucke L, Li W, Schmidt AM, Kindy M, Hyslop PA, Stern DM, Du Yan SS: Rage potentiates $A \beta$-induced perturbation of neuronal function in transgenic mice. EMBO J 2004;23:4096-4105.

16 Origlia N, Righi M, Capsoni S, Cattaneo A, Fang F, Stern DM, Chen JX, Schmidt AM, Arancio O, Yan SD, Domenici L: Receptor for advanced glycation end product-dependent activation of p38 mitogen-activated protein kinase contributes to amyloid $\beta$-mediated cortical synaptic dysfunction. J Neurosci 2008;28:3521-3530.

17 Liliensiek B, Weigand MA, Bierhaus A, Nicklas W, Kasper M, Hofer S, Plachky J, Grone HJ, Kurschus FC, Schmidt AM, Yan SD, Martin E, Schleicher E, Stern DM, Hammerling GG, Nawroth PP, Arnold B: Receptor for advanced glycation end products (RAGE) regulates sepsis but not the adaptive immune response. J Clin Invest 2004;113: 1641-1650.

- 18 Wendt TM, Tanji N, Guo J, Kislinger TR, Qu W, Lu Y, Bucciarelli LG, Rong LL, Moser B, Markowitz GS, Stein G, Bierhaus A, Liliensiek B, Arnold B, Nawroth PP, Stern DM, D'Agati VD, Schmidt AM: RAGE drives the development of glomerulosclerosis and implicates podocyte activation in the pathogenesis of diabetic nephropathy. Am J Pathol 2003;162:1123-1137.

19 Bierhaus A, Haslbeck KM, Humpert PM, Liliensiek B, Dehmer T, Morcos M, Sayed AA, Andrassy M, Schiekofer S, Schneider JG, Schulz JB, Heuss D, Neundorfer B, Dierl S, Huber J, Tritschler H, Schmidt AM, Schwaninger M, Haering HU, Schleicher E, Kasper M, Stern DM, Arnold B, Nawroth PP: Loss of pain perception in diabetes is dependent on a receptor of the immunoglobulin superfamily. J Clin Invest 2004;114:1741-1751.

20 Kalea AZ, Reiniger N, Yang H, Arriero M Schmidt AM, Hudson BI: Alternative splicing of the murine receptor for advanced glycation end-product (RAGE) gene. Faseb J 2009;23:1766-1774.

21 Galichet A, Weibel M, Heizmann CW: Calcium-regulated intramembrane proteolysis of the rage receptor. Biochem Biophys Res Commun 2008;370:1-5.
22 Taguchi A, Blood DC, del Toro G, Canet A, Lee DC, Qu W, Tanji N, Lu Y, Lalla E, Fu C, Hofmann MA, Kislinger T, Ingram M, Lu A, Tanaka H, Hori O, Ogawa S, Stern DM, Schmidt AM: Blockade of RAGE-amphoterin signalling suppresses tumour growth and metastases. Nature 2000;405:354-360.

-23 Nakamura K, Yamagishi S, Adachi H, Matsui T, Kurita-Nakamura Y, Takeuchi M, Inoue H, Imaizumi T: Serum levels of soluble form of receptor for advanced glycation end products (sRAGE) are positively associated with circulating ages and soluble form of VCAM-1 in patients with type 2 diabetes. Microvasc Res 2008;76:52-56.

$>24$ Harja E, Bu DX, Hudson BI, Chang JS, Shen X, Hallam K, Kalea AZ, Lu Y, Rosario RH, Oruganti S, Nikolla Z, Belov D, Lalla E, Ramasamy R, Yan SF, Schmidt AM: Vascular and inflammatory stresses mediate atherosclerosis via RAGE and its ligands in $\mathrm{APOE}^{-/-}$mice. J Clin Invest 2008;118:183194.

25 Shankar GM, Li S, Mehta TH, Garcia-Munoz A, Shepardson NE, Smith I, Brett FM, Farrell MA, Rowan MJ, Lemere CA, Regan CM, Walsh DM, Sabatini BL, Selkoe DJ: Amyloid$\beta$ protein dimers isolated directly from Alzheimer's brains impair synaptic plasticity and memory. Nat Med 2008;14:837-842.

26 Lesne S, Koh MT, Kotilinek L, Kayed R, Glabe CG, Yang A, Gallagher M, Ashe KH: A specific amyloid- $\beta$ protein assembly in the brain impairs memory. Nature 2006;440: 352-357.

27 Thangthaeng N, Sumien N, Forster MJ: Dissociation of functional status from accrual of CML and RAGE in the aged mouse brain. Exp Gerontol 2008;43:1077-1085.

28 Luo Y, Niu F, Sun Z, Cao W, Zhang X, Guan D, Lv Z, Zhang B, Xu Y: Altered expression of $A \beta$ metabolism-associated molecules from $\mathrm{D}$-galactose $/ \mathrm{AlCl}_{3}$ induced mouse brain. Mech Ageing Dev 2009;130:248-252.

29 Shimizu E, Kawahara K, Kajizono M, Sawada M, Nakayama H: Il-4-induced selective clearance of oligomeric $\beta$-amyloid peptide $_{1-42}$ by rat primary type 2 microglia. J Immunol 2008;181:6503-6513.

30 Yamamoto M, Kiyota T, Walsh SM, Liu J, Kipnis J, Ikezu T: Cytokine-mediated inhibition of fibrillar amyloid- $\beta$ peptide degradation by human mononuclear phagocytes. J Immunol 2008;181:3877-3886.

$\checkmark 31$ Redmond WL, Sherman LA: Peripheral tolerance of CD8 $\mathrm{T}$ lymphocytes. Immunity 2005;22:275-284. 